\title{
照射糖培養液の微生物生育に及ぼす影響
}

\author{
伊藤 均 \\ 日本原子力研究所高崎研究所 ·研究嘱託（₹ 370-0884 群馬県高崎市八幡町 935-6）
}

\section{Effects of Microbial Growth in Irradiated Sugar Media}

\author{
Hitoshi Ito \\ Research advisor, Takasaki Radiation Chemistry Research Establishment, Japan Atomic Energy Research Institute, \\ 935-6 Yahata, Takasaki, Gunma, 370-0884, JAPAN
}

\begin{abstract}
Summary
Effects of gamma-irradiated media containing $1 \%$ glucose on the growth of microorganisms were investigated using with strains of Saccharomyces cerevisiae 52a, Escherichia coli A4-1, S2 and Bacillus subtilis IAM1069 after irradiated at 16kGy under air-equilibrium or oxygen-equilibrium. Same growth were observed when cultivated with S.cerevisiae in the glucose media after irradiated at $16 \mathrm{kGy}$ under air-equilibrium or $16 \mathrm{kGy}$ under oxygen-equilibrium compared with heat sterilization. In the case of $E$. coli A4-1 and S2, a little inhibition of growth were observed in irradiated media especially at oxygen-equilibrium irradiation. Strong growth inhibitions were observed in irradiated media when cultivated with B.subtilis especially remarkable at oxygenequilibrium irradiation. Irradiation of $1 \%$ glucose media caused $\mathrm{pH}$ drops from 7.4 to 6.6 at air-equilibrium irradiation and 6.4 at oxygen-equilibrium irradiation whereas 6.8 at heat sterilization. When these media were neutralized to $\mathrm{pH} 7.0-7.2$, no inhibitions of growth were observed on B.subtilis between irradiated and heat sterilized media. These results indicated that cytotoxicity effects were not observed in irradiated media on these microorganisms. Similar $\mathrm{pH}$ drops were observed in sugar media at glucose, xylose and lactose after $16 \mathrm{kGy}$ irradiation whereas observed strong drop of $\mathrm{pH}$ at xylose by heat sterilization. From these results, $\mathrm{pH}$ drop of sugar media after irradiation must be considered for the design and interpretation on media effects at the wholesomeness evaluation of irradiated foods.
\end{abstract}

\section{緒言}

米国等の食品照射反対運動では現在でも 1969 年 に Schubert が報告した総説「照射食品および食品成 分の変異原性と細胞毒性」を反対運動の重要な論拠 の一つに用いている ${ }^{1)}$ 。この総説では $1 \%$ 糖含有培 養液等を照射すると微生物や植物細胞, 哺乳動物細 胞, 原生動物細胞に対し細胞毒性や変異原性を示す と述べている。これに対し，わが国ではガンマ線照 射した糖液や糖・アミノ酸混合液の変異原性につい

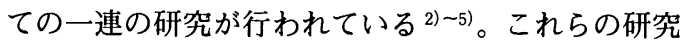
では, 糖液を照射すると弱変異原性物質が若干生成 するが果汁抽出液や動物体内で無毒化され, 糖・ア
ミノ酸混合液では加熱の場合と異なり照射による変 異原性物質の生成はないと報告されている。しか し，これらの研究では細胞毒性に及ぼす照射の影響 についてほとんど検討されていない。糖類は水溶液 の状態では放射線で分解されやすいが, 熱処理でも 著しく分解するものがある。そこで，本研究では糖 発醅能を有する酵母菌や細菌類を用いて照射糖培養 液と蒸気滅菌糖培養液における生育能に及ぼす糖分 解物の影響について検討を行った。

\section{実験方法}

\section{1．照射糖培養液の睭整}

糖培養液はペプトン無添加培養液（glucose 10g, 
$\mathrm{NH}_{4} \mathrm{NO}_{3} 1 \mathrm{~g}, \mathrm{~K}_{2} \mathrm{HPO}_{4} 1 \mathrm{~g}, \mathrm{NaCl} 0.5 \mathrm{~g}, \mathrm{MgSO}_{4} \cdot 7 \mathrm{H}_{2} \mathrm{O} 0.5 \mathrm{~g}$, 蒸 留水 $11, \mathrm{pH}$ 7.4）とペプトン添加培養液（glucose $10 \mathrm{~g}$, polypeptone $2 \mathrm{~g}, \mathrm{NaCl} 0.5 \mathrm{~g}, \mathrm{~K} 2 \mathrm{HPO} 40.3 \mathrm{~g}$, 蒸留水 $11, \mathrm{pH}$ 7.4）を準備した。この糖培養液を $250 \mathrm{ml}$ 容の通気瓶 2 本に約半量ずつ入れ, 片方は酸素ガスを約 10 分通 気後に密封した。他の通気瓶は通気口を綿栓した。 ガンマ線源は 10 万キュリー (4.0PBq) の Co-60 板状 線源を用い, $4.0 \mathrm{kGy} / \mathrm{h}$ の位置での両面照射で $16 \mathrm{kGy}$ 照射した。照射位置の線量率は Fricke 鉄線量 計とアラニン線量計であらかじめ測定して両者の吸 収線量が一致することを確認しておいた。また，比 較としてxylose, lactose 培養液も照射した。しか し, 微生物によってはxylose や lactose 発酵能がない ものがあるため, 培養試験には用いなかった。一 方, 非照射の糖培養液は $120^{\circ} \mathrm{C} \cdot 15$ 分で蒸気滅菌し. ておいた。これらの処理済み培養液は $4{ }^{\circ} \mathrm{C} て ゙ 1$ 夜保 存して培養試験に供した。

\section{2. 供試菌株}

Saccharomyces cerevisiae 52a 株は ascospore 形成 しやすい野生酵母菌である。Escherichia coli $\mathrm{S} 2$ 株は 下水污泥から分離され ${ }^{6}$, ペプトン無添加の合成培 地でも活発に生育する。E. coli A4-1株は牛肉より分 離されペプトン無添加培地では生育できず, ソルビ

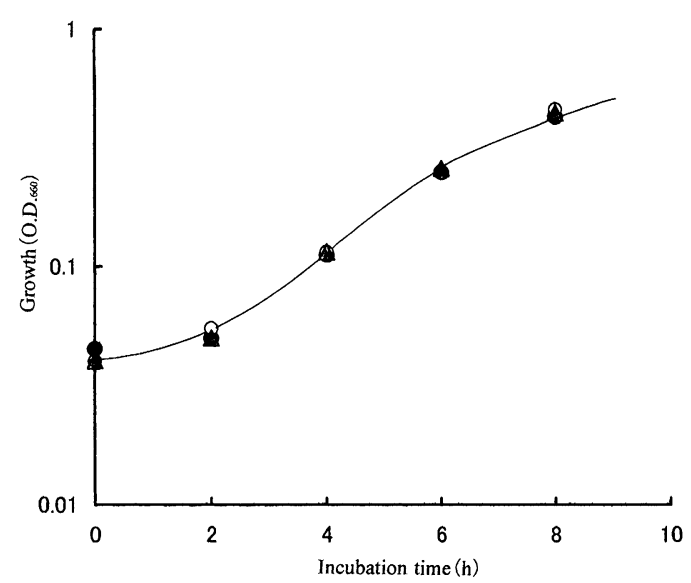

Fig. 1 Growth of S. cerevisiae 52a in $1 \%$ glucose medium containing polypeptone at $30^{\circ} \mathrm{C}$ after irradiation or heat sterilization.

: heat sterilization,

$\bigcirc$ : irradiated $16 \mathrm{kGy}$ under air-equilibrium,

$\Delta$ : irradiated $16 \mathrm{kGy}$ under oxygen-equilibrium
トール分解能がない7)。Bacillus subtilis IAM1069 株は 低温下で簡単に溶菌を起こす菌である。

\section{3. 培養試験}

照射糖培養液または蒸気滅菌糖培養液 $9 \mathrm{ml}$ を各 7 本の L 字管に無菌的に注入し, 各種菌株培養液 $1 \mathrm{ml}$ を加えシリコ栓をして, $30^{\circ} \mathrm{C}$ で振とう培養を行っ た。2 時間ごとにL字管を採取し，660nm の吸光度 （島津 UV-150 型）で生育度を測定した。また, 必 要に応じて糖培養液の $\mathrm{pH}$ を測定し, 培養液の着色 は肉眼で観察した。

\section{実験結果}

S. cerevisiae の場合 Fig. 1 に示すようにペプトン添 加培養液での生育は蒸気滅菌と照射処理での差は全 く認められなかった。一方, E. coli S2, A4-1 株では 蒸気滅菌培養液に比べ照射培養液での生育が若干抑 制された。ことに酸素ガス飽和下で照射した培養液 での生育抑制が明確に認められた（Fig. 2，3）。

B. subtilis をペプトン無添加培養液（照射前： $\mathrm{pH}$ 7.0）で培養すると, 蒸気滅菌培養液では菌の生育が 認められたのに対し，照射培養液での生育は著しく 抑制され，ことに酸素ガス飽和下で照射された培養 液での生育はほとんど認められなかった。この場合

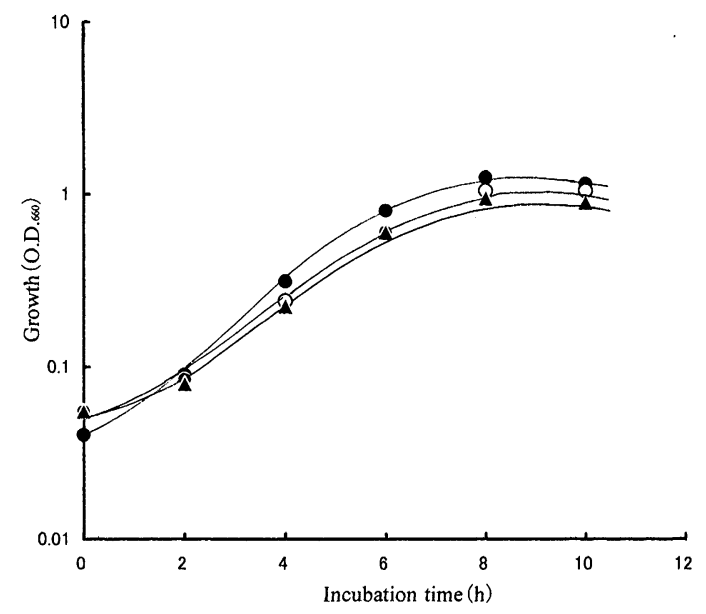

Fig. 2 Growth of $E$. coil S2 in $1 \%$ glucose medium without containing polypeptone at $30^{\circ} \mathrm{C}$ after irradiation or heat sterilization.

: heat sterilization,

$\bigcirc$ : irradiated $16 \mathrm{kGy}$ under air-equilibrium,

$\Delta$ : irradiated $16 \mathrm{kGy}$ under oxygen-equilibrium 


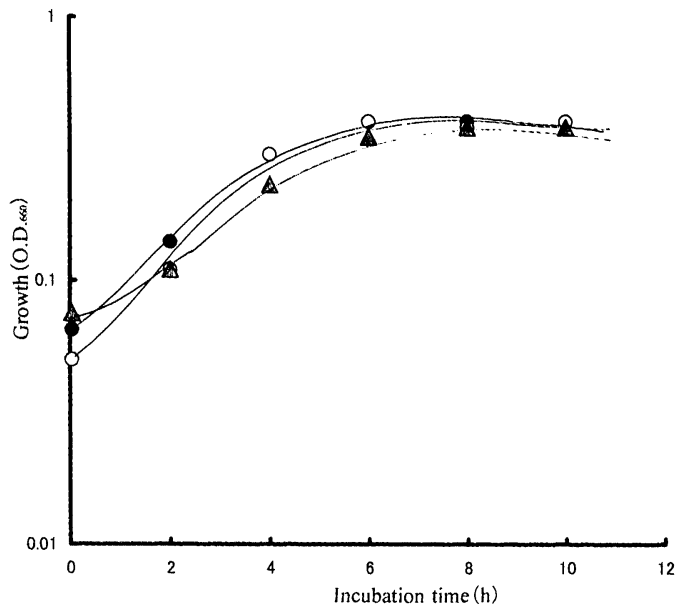

Fig. 3 Growth of E. coil A4-1 in 1\% glucose medium containing polypeptone at $30^{\circ} \mathrm{C}$ after irradiation or heat sterilization.

: heat sterilization, $\bigcirc$ : irradiated 16kGy under air-equilibrium,

$\Delta$ : irradiated $16 \mathrm{kGy}$ under oxygen-equilibrium

の培養液の $\mathrm{pH}$ は蒝気滅菌処理液で 6.4 に対し, 空気 平衡下の照射培養液で 6.2 , 酸素ガス平衡下の照射 培養液で 6.0 であった。B. subtilis の生育がペプトン 無添加培養液で活発でないため, ペプトン添加培養 液で再度培養試験を行った。その結果, Fig. 4 に示 すように照射培養液では菌の生育が明確に抑制され 細胞毒性があるように推察された。この場合の培養 液の $\mathrm{pH}$ は処理前が 7.4 に対し, 蒸気滅菌処理後には 6.8 に低下し, 空気平衡下での照射培養液で 6.6 , 酸 素ガス平衡下での照射培養液で 6.4 に低下した。そこ で, 各処理培養液の $\mathrm{pH}$ を $7.0 \sim 7.2$ に再調整してか ら B. subtilis を培養したところ, Fig. 5 に示すように 各培養液での生育に差は全く認められなくなった。 このことはB. subtilis が他の菌種に比べ $\mathrm{pH}$ 変化に敏 感であることを示しており, 照射による分解生成物 は各種微生物の生育に対し有害でないことを示して いる。

水溶液中の glucose は蒸気滅菌に比べ $16 \mathrm{kGy}$ 照射 で糖分解による $\mathrm{pH}$ 低下が起こりやすいことが明ら かになったので, さらに xylose や lactose についても 分解による $\mathrm{pH}$ 低下を比較した。その結果, Table 1 に示すように照射による $\mathrm{pH}$ 低下は糖の種類による 差は少なかった。一方, 蒸気滅菌処理ではxyloseの

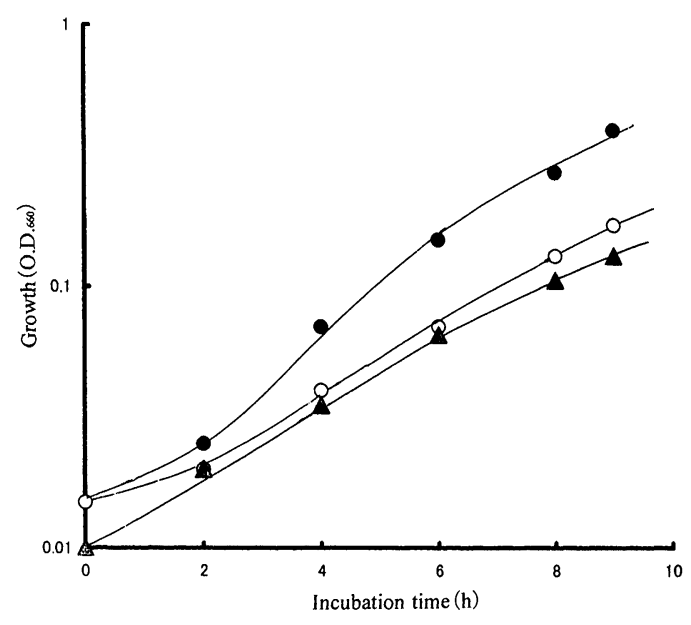

Fig. 4 Growth of B. subtilis IAM1069 in 1\% glucose medium containing polypeptone at $30^{\circ} \mathrm{C}$ after irradiation or heat sterilization.

: heat sterilization,

$\bigcirc$ : irradiated $16 \mathrm{kGy}$ under air-equilibrium,

$\Delta$ : irradiated $16 \mathrm{kGy}$ under oxygen-equilibrium

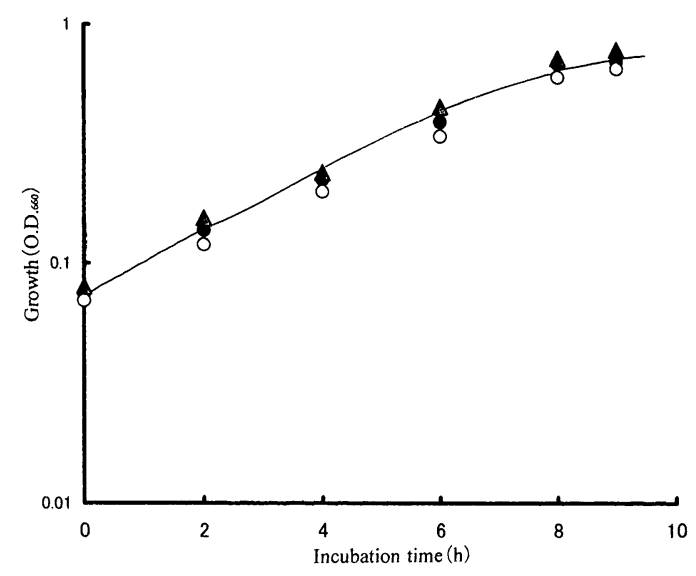

Fig. 5 Growth of B. subtilis IAM1069 in irradiated or heat sterilized $1 \%$ glucose medium containing polypeptone after adjustment of $\mathrm{pH}$ to 7.0-7.2.

: heat sterilization,

$\bigcirc$ : irradiated $16 \mathrm{kGy}$ under air-equilibrium,

$\boldsymbol{\Delta}$ : irradiated $16 \mathrm{kGy}$ under oxygen-equilibrium

$\mathrm{pH}$ 低下が著しく認められ糖の種類による差が大き かった。また, 蒸気滅菌処理では糖培養液が薄茶褐 色に着色したが照射糖培養液では着色は認められな かった。 
Table 1. Change of $\mathrm{pH}$ and color on $1 \%$ sugar media after $16 \mathrm{kG}$ irradiation under airequilibrium or heat sterilization.

\begin{tabular}{|c|c|c|c|c|}
\hline \multicolumn{2}{|l|}{ Treatment of media } & Glucose & Xylose & Lactose \\
\hline \multicolumn{5}{|c|}{ Sugar medium without containing polypeptone (pH 7.4) } \\
\hline \multirow[t]{2}{*}{ heat sterilization } & $\mathrm{pH}$ & 7.12 & 6.05 & 6.86 \\
\hline & color & \pm & ++ & + \\
\hline \multirow[t]{2}{*}{$16 \mathrm{kGy}$ irradiation } & $\mathrm{pH}$ & 6.94 & 9.82 & 6.86 \\
\hline & color & - & - & - \\
\hline \multicolumn{5}{|l|}{ Sugar medium containing polypeptone (pH 7.4) } \\
\hline \multirow[t]{2}{*}{ heat sterilization } & $\mathrm{pH}$ & 7.12 & 6.03 & 6.88 \\
\hline & color & \pm & ++ & + \\
\hline \multirow[t]{2}{*}{ 16kGy irradiation } & $\mathrm{pH}$ & 6.76 & 6.70 & 6.81 \\
\hline & color & - & - & - \\
\hline
\end{tabular}

\section{考 察}

糖類を乾燥下で照射すると有機酸のほかにアルデ ヒド類も生成するが，水溶液中で照射すると有機酸 が主に生成すると報告されている8)。すなわち，水 溶液中で glucose を照射するとグルコン酸, グリセ リン酸, デオキシグルコン酸類, デオキシケトグル コース類が主に生成し, グルコソンなどの $\alpha$ ージカ ルボニル化合物類なども若干量生成することがわ かっている。これらの化合物の中でグルコソンなど の $\alpha$ ージカルボニル化合物に弱変異原性を示すもの があるが, $10 \mathrm{kGy}$ の照射では変異原性を示すのに必 要な量の 100 分の 1 程度しか生成しないと報告され ている2)。

本研究の結果では S. cerevisiae は $\mathrm{pH} 6.0$ 以下でも生 育が良好なため, 蒸気滅菌処理と照射処理糖培養液 で生育に差が認められないのは当然のことであろ う。E. coliも比較的低 $\mathrm{pH}$ で生育が可能であり, 照 射糖培養液で生育が若干抑制されたのは $\mathrm{pH}$ 低下に よる影響であろう。B. subtilis は高 $\mathrm{pH}$ での生育を好 み, しかも化学物質の細胞透過性が高い菌である。 したがって，照射糖培養液で $\mathrm{pH}$ が著しく低下すれ ば生育が抑制されるのは当然である。しかも，培養 液成分の影響が現れやすい菌であるにもかかわらず $\mathrm{pH}$ を 7.0 以上に再調整すると照射の影響が認められ なくなったという結果は細胞毒性を示す物質がほと んど生成されないことを示している。

Schubert は照射により生成される過酸化水素や有
機過酸化物が生物細胞に悪影響を与えると述べてい る ${ }^{1)}$ 。過酸化水素の生成量は蒸留水中で $100 \mu \mathrm{M}$ 程 度と報告されているが9)，糖培養液中では培地成分 が存在するため生成量は微量と思われ，しかも照射 後に急速に分解されてしまう。照射による有機過酸 化物の生成量は脂質でも加熱調理より少ないことが 報告されており ${ }^{10)}$, 本研究の結果でも細胞毒性を示 す結果は得られていない。したがって, Schubert が 引用した多くの研究報告は照射による培養液の $\mathrm{pH}$ 低下など実験条件の設定に問題のある結果が多く, それらの結果から照射食品の安全性を評価するのは 問題であろう。なお, 糖の多くは加熱調理でも分解 して有機酸類などを生成するが, その分解生成物の 種類は放射線と大差ないものと思われる。

\section{文献}

1) J. Schubert: Mutagenicity and cytotoxicity of irradiated foods and food components, Bull. Wld. Hlth. Org., 41, 873-904, (1969).

2 ) 川岸舜朗, 大澤俊彦, 公文春枝: ガンマ線照射 糖液の変異原性およびその抑制, 食品照射研究 委員会・研究成果最終報告書, 日本アイソトー プ協会, 135-149, (1992).

3 ) 祖父尼俊雄, 石舘 基, 林 真, 能美健彦, 松 岡厚子, 松井直子, 鈴木孝昌, 渡辺雅彦, 本間 正充, 山田雅巳, 山崎奈緒美, 松井恵子: ガン マ線照射グルコースについての変異原性試験, 食品照射研究委員会. 研究成果最終報告書, 日 
本アイソトープ協会，150-181,(1992)。

4）坂本京子, 岩原繁雄，川上久美子：ガンマ線照 射グルコースの変異原性, 食品照射研究委員 会・研究成果最終報告書, 日本アイソトープ協 会, 182-191,(1992).

5 ）坂本京子：糖・アミノ酸混合物の加熱物の変異 原性に対するガンマ線照射の影響, 食品照射研 究委員会・研究成果最終報告書, 日本アイソ トープ協会, 192-203,(1992)。

6 ) H. Ito, H. Watanabe, H. Iizuka and M. Takehisa : Change in microflora of sewage sludge by gammaray irradiation, Agric. Biol. Chem., 47, 2707-2711,
(1983).

7 ）伊藤 均, Harsojo：食肉中での大腸菌 O157： $\mathrm{H} 7$ の放射線殺菌効果, 食品照射， 33，29-31， (1998).

8 ) P. S. Elias and A. J. Cohen (Ed.): Radiation Chemistry of Major Food Components, Elsevier, (1977).

9 ) D. Ewing and S. R. Jones: Superoxide removal and radiation protection in bacteria, Archives of Biochemistry and Biophisics, 254 (1), 53-62, (1987).

10) W. W. Nawar: Volatiles from food irradiation, Food Reviews International, 2 (1), 45-78, (1986).

(2003 年 5 月 22 日受理) 